\title{
The Jews and British Romanticism
}





\section{The Jews and BRITISh ROMANTICISM}

Politics, Religion, Culture

Edited by

Sheila A. Spector 


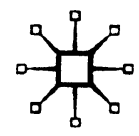

THE JEWS AND BRITISH ROMANTICISM

C) Sheila A. Spector, 2005.

Softcover reprint of the hardcover 1st edition 2005 978-1-4039-6454-0

All rights reserved. No part of this book may be used or reproduced in any manner whatsoever without written permission except in the case of brief quotations embodied in critical articles or reviews.

First published in 2005 by

PALGRAVE MACMILLANTM

175 Fifth Avenue, New York, N.Y. 10010 and

Houndmills, Basingstoke, Hampshire, England RG21 6XS

Companies and representatives throughout the world.

PALGRAVE MACMILLAN is the global academic imprint of the Palgrave Macmillan division of St. Martin's Press, LLC and of Palgrave Macmillan Ltd. Macmillan ${ }^{\otimes}$ is a registered trademark in the United States, United Kingdom and other countries. Palgrave is a registered trademark in the European Union and other countries.

Library of Congress Cataloging-in-Publication Data

The Jews and British romanticism: politics, religion, culture / edited by Sheila A. Spector.

p. $\mathrm{cm}$.

Includes bibliographical references and index.

ISBN 978-1-349-73251-7

ISBN 978-1-137-06285-7 (eBook)

DOI 10.1007/978-1-137-06285-7

1. Jews-Great Britain-History. 2. Judaism and literature-Great Britain.

3. Judaism in literature. 4. Jews in literature. 5. Romanticism-Great Britain.

6. English literature-History and criticism. 7. Great Britain-Ethnic relations.

8. Coleridge, Samuel Taylor, 1772-1834-Criticism and interpretation.

I. Spector, Sheila A., 1946-

DS135.E5J445 2004

305.892' 4041—dc22

2004052795

A catalogue record for this book is available from the British Library.

Design by Newgen Imaging Systems (P) Ltd., Chennai, India.

First edition: January 2005

10987654321

Transferred to Digital Printing 2011 
For the next generation-

\author{
Miriam, Benjamin, Hanan \\ Avra \\ Aiyana, Sophia, Zobara
}





\section{O N T E N T S}

Illustrations $\quad$ ix

Contributors $\quad$ xi

Introduction: The Politics of Religion 1

Sheila A. Spector

Part I British Culture and the Jews

1 Mr. Punch at the Great Exhibition: Stereotypes of Yankee and Hebrew in 1851

Frank Felsenstein

2 Passing for a Jew, On Stage and Off: Stage Jews and Cross-Dressing Gentiles in Georgian England

Michael Ragussis

3 William Blake and the Jewish Swedenborgians Marsha Keith Schuchard

4 Blake and the Book of Numbers: Joshua the Giant Killer and the Tears of Balaam

R. Paul Yoder

\section{Part II Jewish Writers and British Culture}

5 Following the Muse: Inspiration, Prophecy, and Deference in the Poetry of Emma Lyon (1788-1870), Anglo-Jewish Poet Michael Scrivener

6 Identity, Diaspora, and the Secular Voice in the Works of Isaac D'Israeli

Stuart Peterfreund

7 Anglo-Jewish Identity and the Politics of Cultivation in Hazlitt, Aguilar, and Disraeli

Judith W. Page 
8 Charlotte Dacre's Zofloya: The Gothic Demonization of the Jew

Diane Long Hoeveler

Part III The Jews and British Romanticism Outside of England

9 Commerce, Concern, and Christianity: Britain and Middle-Eastern Jewry in the Mid-Nineteenth Century

Reeva Spector Simon

10 Jewish Translations of British Romantic Literature

(1753-1858): A Preliminary Bibliography

Sheila A. Spector

11 The Reader as Witness: "City of the Killings" and Bialik's Romantic Historiography

Lilach Lachman

\section{Part IV Coda: Coleridge and Judaica}

12 Coleridge's Misreading of Spinoza

Stanley J. Spector

13 Mendelssohn and Coleridge on Words, Thoughts, and Things

Frederick Burwick

14 Standing at Mont Blanc: Coleridge and Midrash

Lloyd Guy Davies

Bibliography

Index 


\section{ILLUSTRATIONS}

1.1 Title page to Punch, or the London Charivari 19

1.2 "Going Before the Wind," Punch, or the London Charivari 21

1.3 John Leech, "Bloomerism-An American Custom," Punch, or the London Charivari 25

1.4 Venus de' Medici, Uffizi Gallery (Tribuna), Florence 26

1.5 Hiram Powers, The Greek Slave, Corcoran Gallery, Washington, D.C.

1.6 John Tenniel, "The Virginian Slave. Intended as a Companion to Power's 'Greek Slave," Punch, or the London Charivari

1.7 "Sample of American Manufacture," Punch, or the London Charivari

1.8 John Leech, "Distressing Case of Desertion," Punch, or the London Charivari

1.9 "Dressing for a Masquerade. Mr. D-sr-li as a Great Protectionist Leader," Punch, or the London Charivari

1.10 "Christmas in the Minories," Punch, or the London Charivari

1.11 John Leech, "The Dealer in Old Clothes Teaching the Young Idea How to Steal," Punch, or the London Charivari

7.1 Gough maps 177 "Bear Place"

7.2 Gough maps 177 "Belvidere House"

7.3 Gough maps 177 "Prospect Place" 



\title{
C O N T R I B U T O R S
}

\begin{abstract}
Frederick Burwick, Professor of English and Comparative Literature at the University of California at Los Angeles, held visiting positions in Germany at the Universities of Würzburg, Siegen, Göttingen, and Bamberg. $\mathrm{He}$ has also lectured at the Universities of Heidelberg, Köln, Giessen, Leipzig, and Jena in Germany, as well as Oxford and Cambridge in England. With an interdisciplinary approach to literature, he has explored the interactions of literature with art, science, music, and theater. Author and editor of twenty books and close to a hundred articles, his research is dedicated to problems of perception, illusion, and delusion in literary representation and theatrical performance. With Paul Douglass, he edited A Selection of Hebrew Melodies, Ancient and Modern of Lord Byron and Isaac Nathan (Tuscaloosa: University of Alabama Press, 1988), which was marketed with a recording of the songs. He has been named Distinguished Scholar by both the British Academy (1992) and the Keats-Shelley Association (1998).
\end{abstract}

Lloyd Guy Davies received his Ph.D. in Literature from Duke University's Graduate Program in Literature. He is Professor of English Literature at Western Kentucky University with research interests in Romanticism, literary theory, and Jewish studies. He has published articles on Romanticism and on traditional Judaic textual study as a theoretical model for contemporary literary criticism, and is currently completing a book, inspired by the work of Harold Fisch, entitled Romantic Hebraism: A Covenantal Reading of English Romanticism.

Frank Felsenstein's book, Anti-Semitic Stereotypes: A Paradigm of Otherness in English Popular Culture, 1666-1938 (Baltimore: The Johns Hopkins University Press, 1995), examined the representation of the Jews in English popular culture from 1660 to 1830 . He is at present working on a parallel study of depictions of the Jews during the Victorian era. Felsenstein is Reed D. Voran Honors Distinguished Professor of Humanities at Ball State University.

Diane Long Hoeveler is Professor of English and Coordinator of Women's Studies at Marquette University, Milwaukee, Wisconsin. She is author of Romantic Androgyny: The Women Within (University Park, PA: Pennsylvania State University Press, 1990) and Gothic Feminism: The Professionalization of Gender from Charlotte Smith to the Brontës (University Park, PA: Pennsylvania 
State University Press, 1998), and coauthor of Charlotte Brontë (New York: Twayne Publishers, 1997) and the Historical Dictionary of Feminism (Lanham, MD: Scarecrow Press, 1996; 2004). Edited or coedited works include Comparative Romanticisms: Power, Gender, Subjectivity (Columbia, SC: Camden House, 1998), Women of Color: Defining the Issues, Hearing the Voices (Westport, CN: Greenwood Press, 2001), Approaches to Teaching "Jane Eyre" (New York: Modern Language Association, 1993), Approaches to Teaching Gothic Fiction: The British and American Traditions (New York: Modern Language Association, 2003), Wuthering Heights: Complete Text with Introduction, Contexts, Critical Essays (Boston: Houghton Mifflin, 2001) and Written on the Bodily Text: Gender and Creativity Across Cultures (forthcoming 2005). In addition, she has published over thirty-five articles on a variety of topics, including the gothic, melodrama, women writers, romanticism, and gender. She is past President of the International Conference on Romanticism (2001-2003), and serves on the editorial board of a number of journals in the field of Romanticism.

Lilach Lachman teaches in the Comparative Literature Department of Tel Aviv University. She has published essays on the poetics of witnessing in Poussin, John Keats, Emily Dickinson, Paul Celan, and Avot Yeshurun. She is the editor of an anthology of Hebrew, Yiddish, and Arabic lullabies, Even Hoshen (forthcoming), and she is currently completing a book on the seminal but neglected Israeli poet, Avot Yeshurun.

Judith W. Page teaches in the English Department and the Center for Jewish Studies at the University of Florida. She is the author of Wordsworth and the Cultivation of Women (Berkeley: University of California Press, 1994) and of Imperfect Sympathies: Jews and Judaism in British Romantic Literature and Culture (New York: Palgrave/Macmillan, 2004). In addition, she has written numerous articles and reviews on Romanticism, including a contribution to the first volume that Sheila Spector edited on British Romanticism and the Jews.

Stuart Peterfreund is Professor of English and Graduate Coordinator at Northeastern University, where he has taught since 1978. The author of three books of poetry, books on Blake and Shelley, and the editor of several collections of essays, Peterfreund has been at work recently on a number of essays that explore the discourses of racial and cultural difference in the late eighteenth and early nineteenth centuries. These essays include "Not for 'Antiquaries,' but for 'Philosophers': Isaac D'Israeli's Talmudic Critique and His Talmudical Way with Literature," which appeared in British Romanticism and the Jews: History, Culture, Literature, as well as forthcoming essays on Mary Wollstonecraft and Orientalism, and on Isaac D'Israeli's response to the theories of the eighteenth-century Dutch physician, physiognomist, and artist, Petrus Camper.

Michael Ragussis is Professor of English at Georgetown University. He is the author of Figures of Conversion: "The Jewish Question" and English 
National Identity (Durham: Duke University Press, 1995), and is currently working on a book-length project entitled Jews and Other "Outlandish Englishmen": Ethnic Performance and National Identity in Georgian England and Beyond.

Marsha Keith Schuchard, an independent scholar from Atlanta, Georgia, received her Ph.D. in English from the University of Texas at Austin. She investigates the influence of esoteric movements on British culture and politics, with special attention to Sabbatian Kabbalism, Illuminist Freemasonry, and Swedenborgianism. Schuchard's essays have appeared in Blake: An Illustrated Quarterly, Studies in Eighteenth-Century Culture, British Journal of Eighteenth-Century Studies, Consortium on Revolutionary Europe, and Esoterica, as well as anthologies such as Secret Texts: The Literature of Secret Societies, ed. Marie Mulvey Roberts and Hugh Ormsby-Lennon (New York: AMS Press, 1995); Leibniz, Mysticism, and Religion, ed. Allison P. Coudert, Richard H. Popkin, and Gordon M. Weiner (Boston: Kluwer Academic Publishers, 1998); Blake, Politics, and History, ed. Jackie DiSalvo, G. A. Rosso, and Christopher Z. Hobson (New York: Garland, 1998); Blake in the Nineties, ed. Steve Clark and David Worrall (New York: St. Martin's Press, 1999). She recently published Restoring the Temple of Vision: Cabalistic Freemasonry and Stuart Culture (Leiden: Brill, 2002), and has a new book, William Blake and the Sexual Basis of Spiritual Vision, forthcoming from London: Random House.

Michael Scrivener is the author of three books on Romanticism and politics, the most recent of which is Seditious Allegories: John Thelwall and Jacobin Writing (University Park, PA: Pennsylvania State University Press, 2001). Scrivener currently is working on a study of modernity and Jewish representations in nineteenth-century literature and culture.

Reeva Spector Simon is a Research Scholar at the Middle East Institute, Columbia University. She is the author of Iraq Between the Two World Wars: The Militarist Origins of Tyranny (updated ed., New York: Columbia University Press, 2004), and The Middle East in Crime Fiction: Mysteries, Spy Novels, and Thrillers from 1916 to the 1980s (New York: L. Barber Press, 1989); and she is coeditor of The Jews of the Middle East and North Africa in Modern Times (New York: Columbia University Press, 2003), and the forthcoming The Creation of Iraq 1914-1921.

Sheila A. Spector, an independent scholar, has devoted her career to studying the intersection between British culture and Judaica. In addition to compiling Jewish Mysticism: An Annotated Bibliography on the Kabbalah in English (New York: Garland, 1984), she has written two books on Blake"Glorious incomprebensible": The Development of Blake's Kabbalistic Language and "Wonders Divine": The Development of Blake's Kabbalistic Myth (both published by Lewisburg, PA: Bucknell University Press, 2001); and she edited British Romanticism and the Jews: History, Culture, Literature (New York: Palgrave/Macmillan, 2002). 
Stanley J. Spector, who received the Ph.D. in Philosophy from the University of Colorado, specializes in twentieth-century European thought, including phenomenology, transcendental philosophy, existential philosophy and hermeneutics. He has presented several essays at the Southwest Texas Popular Culture Association, including "Bound to Cover Just a Little More Ground: A Heideggerian Reflection on the Grateful Dead," and "Who is Dionysos, and Why Does He Keep Following Me Everywhere?," published in Dead Letters, volume II. His "Dionysus and the Dead: A Nietschean Perspective," will be included in N. Merriweather's It All Rolls Into One: Rapture, Dionysus, Nietzsche and the Grateful Dead (Berkeley: University of California Press, forthcoming).

R. Paul Yoder is Associate Professor of English at the University of Arkansas at Little Rock. He is the coeditor (with Wallace Jackson) of Approaches to Teaching Pope's Poetry (New York: Modern Language Association, 1993), and Critical Essays on Alexander Pope (New York: G. K. Hall, Toronto: Maxwell Macmillan Canada, and New York: Maxwell Macmillan International, 1993). $\mathrm{He}$ has also published essays on Milton, Pope, Thomas Gray, Samuel Richardson, Blake, and Wordsworth. 